\title{
PENINGKATAN PERAN PENJAMINAN MUTU SOAL UNTUK MENINGKATKAN HASIL BELAJAR SISWA SD MUHAMMADIYAH 9 "PANGLIMA SUDIRMAN" MALANG
}

\author{
Sony Darmawan \\ SD Muhammadiyah 9 "Panglima Sudirman" Malang \\ sonydarmawan79@gmail.com
}

\begin{abstract}
In order to implement the assessment standard in SD Muhammadiyah 9 "Panglima Sudirman" Malang, this article will describe the implementation of quality assurance of the problem to improve student learning outcomes. This implementation description is very useful to determine the steps or policies related to the assessment standard, which in turn is expected to improve students' learning outcomes in SD Muhammadiyah 9 "Panglima Sudirman" Malang.
\end{abstract}

Keywords: Quality assurance, Assessment

\begin{abstract}
Abstrak: Dalam rangka melaksanakan standar penilaian di SD Muhammadiyah 9 "Panglima Sudirman" Malang, artikel ini akan mendeskripsikan mengenai implementasi penjaminan mutu soal untuk meningkatkan hasil belajar siswa. Deskripsi implementasi ini sangat berguna untuk menentukan langkah atau kebijakan terkait dengan standar penilaian, yang pada akhirnya diharapkan dapat meningkatkan hasil belajar para siswa di SD Muhammadiyah 9 "Panglima Sudirman" Malang.
\end{abstract}

Kata Kunci: Penjaminan mutu, Penilaian

\section{PENDAHULUAN}

Standar Nasional Pendidikan terdiri atas 8 (delapan) standar, salah satunya adalah Standar Penilaian yang bertujuan untuk menjamin: a. perencanaan penilaian peserta didik sesuai dengan kompetensi yang akan dicapai dan berdasarkan prinsip-prinsip penilaian; b. pelaksanaan penilaian peserta didik secara profesional, terbuka, edukatif, efektif, efisien, dan sesuai dengan konteks sosial budaya; dan c. pelaporan hasil penilaian peserta didik secara objektif, akuntabel, dan informatif. Standar penilaian pendidikan ini disusun sebagai acuan evaluasi bagi pendidik, satuan pendidikan, dan pemerintah pada satuan pendidikan untuk jenjang pendidikan dasar dan menengah (104, 2014). Khusus untuk jenjang pendidikan dasar, pelaksanaan penilaian sangat penting untuk dilaksanakan di SD sebagai bagian untuk mempersiapkan generasi penerus bangsa yang berkualitas (Hadiana, 2015). Siswa SD yang berkualitas adalah siswa yang mampu beradaptasi secara cepat terhadap perubahan yang terjadi serta mampu memberikan respon dengan kritis dan kreatif tantangan yang dihadapi, terutama di masa mendatang. Generasi penerus yang berkualitas di tingkat SD yang menjadi salah satu pondasi bagi jenjang pendidikan yang lebih tinggi (Lambertus, 2009).

Hal senada di atas, juga dilakukan SD Muhammadiyah 9 "Panglima Sudirman" Malang sebagai salah satu amal usaha muhammadiyah. SD yang berada di wilayah Kota Malang ini berkomitmen untuk selalu meningkatkan kualitas pendidikan. Termasuk di dalamnya adalah komitmen untuk selalu meningkatkan hasil belajar para siswa sebagai pondasi pengembangan kualitas dirinya pada 
tahap pendidikan selanjutnya (Pratistya \& Abdullah, 2012). Dalam rangka peningkatan hasil belajar, berbagai program telah dilakukan oleh SD yang berada di kecaman klojen ini. Seperti pelatihan, seminar atau workshop yang diadakan oleh Diknas maupun oleh sekolah secara mandiri. Namun SD yang dibina oleh Universitas Muhammadiyah Malang ini masih memiliki beberapa kendala dalam peningkatan hasil belajar siswa. Hal ini diketahui berdasarkan hasil refleksi pada kegiatan penelitian yang berjudul "Model Pembelajaran Pendidikan Karakter Terintegrasi Pada Pembelajaran Tematik Di SD Muhammadiyah 9 Kota Malang" tahun 2012-2013 (Setyaningrum, dkk, 2012) dan pengabdian "Pelatihan Penerapan Pembelajaran Tematik Bagi Guru-Guru Kelas 1-3 SD Muhammadiyah 9 Malang" tahun 2009 (Cholily, dkk, 2009), bahwa SD muhammadiyah 9 malang ini belum memiliki acuan mengenai pelaksanaan penilaian dalam pembelajaran tematik maupun pelaksanaan penilaian untuk para siswa kelas 6. Oleh karenanya, sebagian Guru kesulitan dalam melaksanakan penilaian. Kesulitan tersebut berkenaan dengan penentuan kisi-kisi soal, penyusunan soal dalam pembelajaran tematik pada saat PAS (Penilaian Akhir Semester) serta penyiapan siswa kelas 6 yang akan menjalani ujian sekolah. Khusus siswa kelas 6, perlu mendapat perhatian yang lebih mendalam. Hal ini karena pembelajaran yang dilakukan adalah pembelajaran tematik. Sedangkan ujian sekolah dalam bentuk ujian per mata pelajaran. Berbagai kendala ini juga menyebabkan soal-soal yang diberikan ada siswa pada saat UAS selalu sama dari tahun ke tahun. Oleh karenanya, mulai tahun 2015 dibentuk tim penjaminan mutu soal sebagai bagian usaha untuk meningkatkan kualitas pelaksanaan penilaian. Tim penjamin mutu soal, merupakan tim yang secara struktural berada di bawah koordinasi kepala urusan kurikulum (Azis, 2014). Berkenaan dengan penjaminan mutu soal untuk meningkatkan hasil belajar siswa ini akan diuraikan secara mendalam dalam artikel yang berjudul "Implementasi Penjaminan Mutu Soal Untuk Meningkatkan Hasil Belajar Siswa SD Muhammadiyah 9 "Panglima Sudirman" Malang".

\section{A. Analisis situasi SD Muhammadiyah 9 "Panglima Sudirman" Malang}

A. Perkembangan

pendidikan di SD Muhammadiyah 9 "Panglima Sudirman" Malang mengalami pasang surut. Mulai berdiri pada tahun 1969, memiliki kurang lebih 10 siswa. Para siswa merupakan putra putri dari para pengurus Muhammadiyah Kota Malang. Situasi dan kondisi pembelajaran tidak jauh dari film laskar pelangi yang memiliki ikon SD Muhammadiyah di wilayah Bangka Belitung. Kemudian pada awal tahun 2000 jumlah siswa hanya 20 anak dari kelas $1-6$. Selanjutnya, para pengurus ranting muhammadiyah berupaya untuk mengembangkan sekolah dan dengan kesungguhan memperoleh jalan dibantu oleh UMM untuk merancang sekolah yang luar biasa. Sekolah melakukan perubahan baik managemen dan fisik, diawal tahun 2003 mulai tumbuh kembali kepercayaan masyarakat. Tantangan berikutnya adalah peningkatan mutu pendidikan untuk memberikan pembelajaran yang sesuai dengan target (Deng \& Yu, 2013a).

B. Sekolah dengan motto "every childs is specials" ini telah melakukan berbagai program peningkatan kualitas pembelajaran. 
Baik yang dilakukan secara mandiri maupun bekerjasama dengan pihak lain. Seperti pelatihan, seminar, workshop atau bahkan melalui kerjasama dalam melakukan kegiatan penelitian maupun pengabdian. Dari berbagai kegiatan inilah, menjadi awal terbentuknya penjaminan mutu soal untuk memberikan solusi terhadap permasalahan yang ada dalam memberikan soal ujian, baik UAS maupun ujian sekolah.

$C$. Permasalahan yang sering muncul berkenaan dengan penilaian hasil belajar para siswa melalui UAS maupun ujian sekolah adalah sebagai berikut.

a) Guru kesulitan dalam membuat kisi-kisi soal (Felder \& Brent, 2005),

b) Soal yang diberikan belum mengakomodasi semua kompetensi dasar. Selalu ada indikator yang terlewati (Deng \& Yu, 2013b).

c) Sebagian besar soal memiliki bobot yang tidak seimbang. Ketidakseimbangan lainnya juga terjadi antara indikator dengan soal yang ada. terdapat soal yang bobotnya mudah semua atau sulit semua.

d) soal-soal yang diberikan pada siswa saat UAS selalu sama dari tahun ke tahun,

e) Guru tidak memiliki format baku dalam membuat soal, baik soal pembelajaran tematik di setiap jenjang kelas maupun soal ujian sekolah di kelas 6. Baik format penulisan maupun format pembuatan soal

f) Tata bahasa soal belum sistematis, bahkan ambigu. Tidak sedikit soal yang sulit dipahami oleh siswa.

g) Dengan motto "every childs is specials", para guru kesulitan mengakomodasi soal PAS untuk siswa ABK. Sehingga perlu pelatihan, seminar, workshop tentang hal ini. Selain itu juga dibutuhkan format baku untuk memeprmudah membuat soalnya.

h) Soal pembelajaran tematik yang dibuat oleh Guru tergantung dari bidang ilmu masing-masing guru. Jika Guru memiliki bidang keilmuan matematika. Maka soal yang dibuat lebih banyak dan lebih detail untuk bidang matematika saja. artinya soal belum sepenuhnya mengakomodasi semua mata pelajaran yang diajarkan dalam pembelajaran tematik. Hal inilah yang selanjutnya menjadi salah satu sebab hasil belajar siswa, khususnya hasil ujian siswa kurang bagus (Felder \& Brent, 2005). Karena antara proses pembelajaran yang dilakukan di kelas tidak sesuai dengan soal yang diberikan saat PAS maupun ujian sekolah di kelas 6.

Dalam rangka mengatasi permasalahan yang ada, sekolah mengambil langkah solusi untuk menyelesaikan permasalahan tersebut. SD binaan UMM ini menyusun tim penjamin mutu soal mulai tahun 2015 (Bundsgaard \& Hansen, 2011).

\section{B. Standar Penilaian Pendidikan}

Undang-Undang Nomor 20

Tahun 2003 tentang Sistem Pendidikan Nasional, Pasal 1 angka 1 menyatakan bahwa "pendidikan adalah usaha sadar dan terencana untuk mewujudkan suasana belajar dan proses pembelajaran agar peserta didik secara aktif mengembangkan potensi dirinya untuk memiliki kekuatan spiritual keagamaan, pengendalian diri, kepribadian, kecerdasan, akhlak mulia, serta keterampilan yang diperlukan dirinya, masyarakat, bangsa dan negara". Selanjutnya, Pasal 3 menegaskan bahwa pendidikan nasional "berfungsi mengembangkan kemampuan dan 
membentuk watak serta peradaban bangsa yang bermartabat dalam rangka mencerdaskan kehidupan bangsa, bertujuan untuk berkembangnya potensi peserta didik agar menjadi manusia yang beriman dan bertakwa kepada Tuhan Yang Maha Esa, berakhlak mulia, sehat, berilmu, cakap, kreatif, mandiri, dan menjadi warga negara yang demokratis serta bertanggung jawab".

Fungsi dan tujuan pendidikan nasional tersebut menjadi parameter utama untuk merumuskan Standar Nasional Pendidikan. Standar Nasional Pendidikan "berfungsi sebagai dasar dalam perencanaan, pelaksanaan, dan pengawasan pendidikan dalam rangka mewujudkan pendidikan nasional yang bermutu". Standar Nasional Pendidikan terdiri atas 8 (delapan) standar, salah satunya adalah Standar Penilaian yang bertujuan untuk menjamin perencanaan penilaian peserta didik sesuai dengan kompetensi yang akan dicapai dan berdasarkan prinsip-prinsip penilaian; pelaksanaan penilaian peserta didik secara profesional, terbuka, edukatif, efektif, efisien, dan sesuai dengan konteks sosial budaya; dan pelaporan hasil penilaian peserta didik secara objektif, akuntabel, dan informatif.

\section{Pengertian Standar Penilaian Pendidikan}

Standar Penilaian Pendidikan adalah kriteria mengenai mekanisme, prosedur, dan instrumen penilaian hasil belajar peserta didik. Penilaian pendidikan sebagai proses pengumpulan dan pengolahan informasi untuk mengukur pencapaian hasil belajar peserta didik mencakup: penilaian otentik, penilaian diri, penilaian berbasis portofolio, ulangan, ulangan harian, ulangan tengah semester, ulangan akhir semester, ujian tingkat kompetensi, ujian mutu tingkat kompetensi, ujian nasional, dan ujian sekolah/madrasah, yang diuraikan sebagai berikut.

a) Penilaian otentik merupakan penilaian yang dilakukan secara komprehensif untuk menilai mulai dari masukan (input), proses, dan keluaran (output) pembelajaran (Yubali, 2013), (Hadiana, 2015).

b) Penilaian diri merupakan penilaian yang dilakukan sendiri oleh peserta didik secara reflektif untuk membandingkan posisi relatifnya dengan kriteria yang telah ditetapkan.

c) Penilaian berbasis portofolio merupakan penilaian yang dilaksanakan untuk menilai keseluruhan entitas proses belajar peserta didik termasuk penugasan perseorangan dan/atau kelompok di dalam dan/atau di luar kelas khususnya pada sikap/perilaku dan keterampilan (Moeljadi Pranata, 2004).

d) Ulangan merupakan proses yang dilakukan untuk mengukur pencapaian kompetensi peserta didik secara berkelanjutan dalam proses pembelajaran, untuk memantau kemajuan dan perbaikan hasil belajar peserta didik.

e) Ulangan harian merupakan kegiatan yang dilakukan secara periodik untuk menilai kompetensi peserta didik setelah menyelesaik an satu Kompetensi Dasar (KD) atau lebih.

f) Ulangan tengah semester merupakan kegiatan yang dilakukan oleh pendidik untuk mengukur pencapaian kompetensi peserta didik setelah melaksanakan $8-9$ minggu kegiatan pembelajaran. Cakupan ulangan tengah semester meliputi seluruh indikator yang merepresentasikan seluruh KD pada periode tersebut. 
g) Ulangan akhir semester merupakan kegiatan yang dilakukan oleh pendidik untuk mengukur pencapaian kompetensi peserta didik di akhir semester. Cakupan ulangan meliputi seluruh indikator yang merepresentasikan semua $\mathrm{KD}$ pada semester tersebut.

h) Ujian Tingkat Kompetensi yang selanjutnya disebut UTK merupakan kegiatan pengukuran yang dilakukan oleh satuan pendidikan untuk mengetahui pencapaian tingkat kompetensi. Cakupan UTK meliputi sejumlah Kompetensi Dasar yang merepresentasikan Kompetensi Inti pada tingkat kompetensi tersebut.

i) Ujian Mutu Tingkat Kompetensi yang selanjutnya disebut UMTK merupakan kegiatan pengukuran yang dilakukan oleh pemerintah untuk mengetahui pencapaian tingkat kompetensi. Cakupan UMTK meliputi sejumlah Kompetensi Dasar yang merepresentasikan Kompetensi Inti pada tingkat kompetensi tersebut.

j) Ujian Nasional yang selanjutnya disebut UN merupakan kegiatan pengukuran kompetensi tertentu yang dicapai peserta didik dalam rangka menilai pencapaian Standar Nasional Pendidikan, yang dilaksanakan secara nasional (Hadi, 2014).

k) Ujian Sekolah/Madrasah merupakan kegiatan pengukuran pencapaian kompetensi di luar kompetensi yang diujikan pada UN, dilakukan oleh satuan pendidikan.

Dalam artikel ini, yang dimaksud penilaian hasil belajar siswa yaitu penilaian yang dilakukan pada saat PAS bagi kelas 1-5 dan ujian sekolah bagi kelas 6 .

\section{Hasil Belajar}

Hasil belajar diketahui sebagai perubahan perilaku yang diperoleh pembelajar setelah mengalami aktivitas belajar (Moeljadi Pranata, 2004). Menurut teori Gagne, hasil belajar diperoleh melalui proses belajar. Menurut Gagne, belajar adalah perubahan yang terjadi dalam kemampuan manusia yang terjadi setelah belajar secara terus-menerus, bukan hanya disebabkan oleh pertumbuhan saja (Hadiana, 2015). Belajar dipengaruhi oleh faktor dalam diri dan faktor dari luar siswa di mana keduanya saling berinteraksi. Hasil dari proses belajar menurut Sudjana (2010:22) adalah kemampuan yang dimiliki siswa setelah siswa menerima pengalaman dalam belajarnya. Robertino Gagne menyatakan bahwa ada lima hasil belajar, diantaranya adalah informasi verbal, kecakapan intelektul, strategi kognitif, sikap dan keterampilan (Hadiana, 2015). Perbedaan hasil belajar dikalangan para siswa disebabkan oleh berbagai alternatif faktor-faktor antara lain faktor kematangan akibat dari kemajuan umur kronologis, latar belakang pribadi masing-masing, sikap dan bakat terhadap suatu bidang pelajaran yang diberikan (Pratistya \& Abdullah, 2012). Hasil belajar tersebut terjadi terutama berkat penilaian guru (Hadiana, 2015). Dalam artikel ini, yang dimaksud hasil belajar merupakan hasil belajar kognitif para siswa yang diukur melalui PAS untuk kelas 1-5 dan ujian sekolah khusus untuk kelas 6 di tingkat SD. 


\section{Implementasi Penjaminan Mutu Soal Untuk Meningkatkan Hasil Belajar Siswa SD Muhammadiyah 9 "Panglima Sudirman" Malang}

Implementasi penjamin mutu soal dilakukan secara terstruktur sesuai dengan SOP yang telah ditetapkan. Langkah pertama yang dilakukan adalah pelaksanaan tugas pokok dan fungsi tim penjaminan mutu soal. Adapun tupoksi sebagai berikut.

1. Pembuatan jadwal PAS dan ujian sekolah. Jadwal ini disesuaikan dengan aturan dari Diknas Kota Malang

2. Pembuatan jadwal pengumpulan soal. Jadwal ini dibuat atas dasar kesepakatan rapat terbatas para Kaur dengan Kepala Sekolah.

3. Penyusunan kisi-kisi soal. Salah satu langkah untuk melakukan penjaminan mutu soal, diawali dengan penyusunan kisi-kisi soal. Hal ini dilakukan untuk mengidentifikasi kelengkapan soal sesuai dengan indikator mata pelajaran. Pada akhirnya terjadi kesesuaian antara materi pembelajaran dengan soal-soal pada PAS maupun Ujian sekolah.

4. Pembuatan format penyusunan soal (tamplate). Tamplate ini tidak membedakan antara tamplate soal untuk anak reguler. Sekolah memberikan ketentuan yang sama mengenai ukuran kertas, batas penulisan, ukuran font, pemilihan font serta spasi.

5. Penentuan tim penyusun soal. Tim dipimpin oleh Kaur Kurikulum dengan anggota tim dari Guru dan tim penjamin mutu.

6. Telaah soal dilakukan untuk soal siswa reguler dan ABK. Telaah dilakukan dengan menggunakan instrumen telaah soal. Instrumen tersebut sebagaimana tabel di bawah ini.

Tabel 1. Telaah Soal Berdasarkan kesesuaian Materi, Konstruksi, Bahasa dan Penulisan Soal

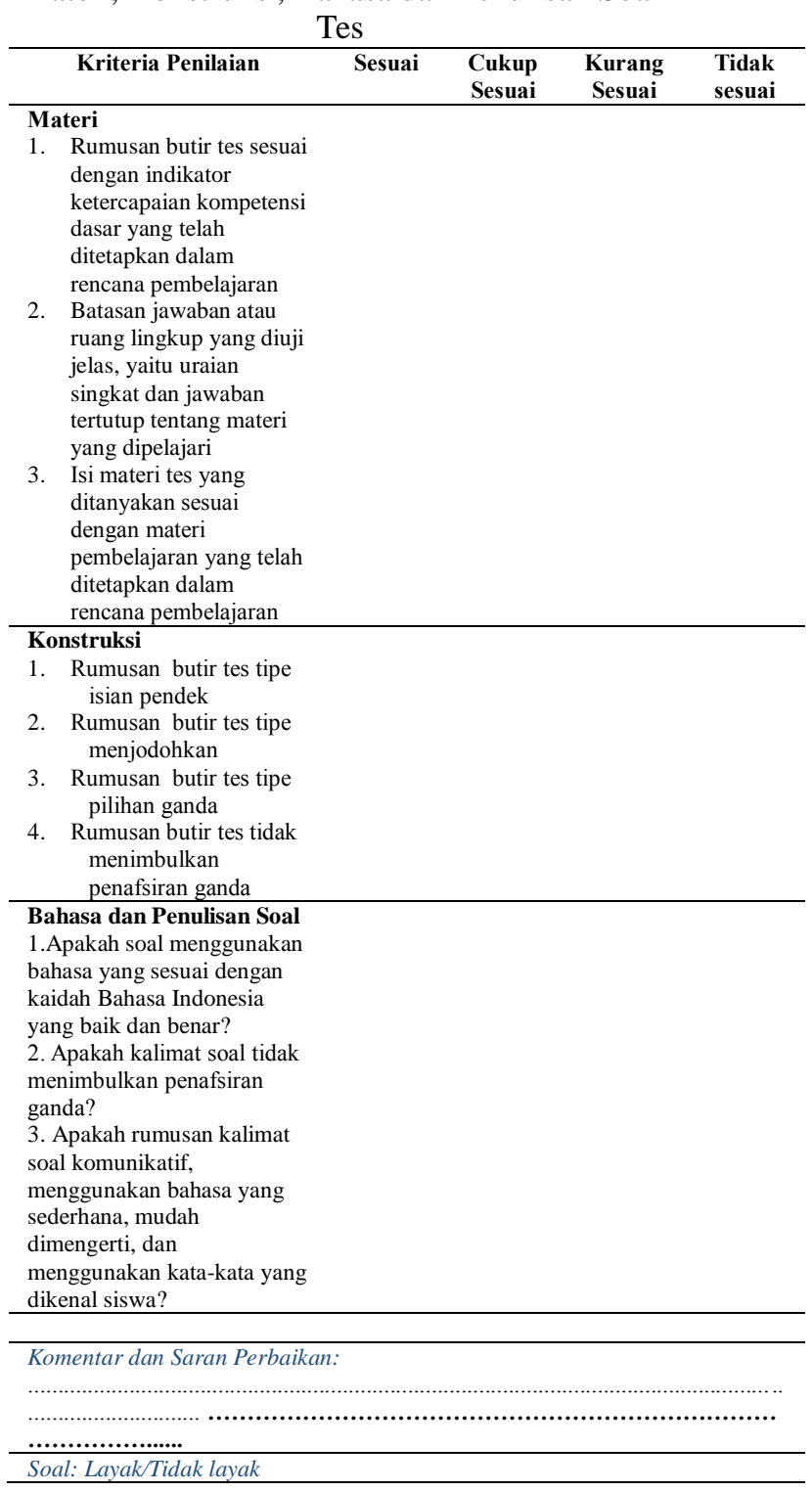

Berdasarkan tupoksi di atas, maka tim penjamin mutu soal menghasilkan luaran kegiatan berupa jadwal PAS dan ujian sekolah, jadwal pengumpulan soal, kisi-kisi soal, format penyusunan soal (tamplate), tim penyusun soal serta hasil telaah soal. Pada saat telaah soal tim penjamin mutu soal melakukan telaah soal sesuai dengan tabel di atas. Jika soal dinilai sudah layak maka soal akan diujikan, namun jika belum layak, maka soal harus direvisi terlebih dahulu 
sebelum diujikan. Secara umum implementasi penjamin mutu soal di SD Muhammadiyah 9 Kota Malang sebagaimana bagan di bawah ini.

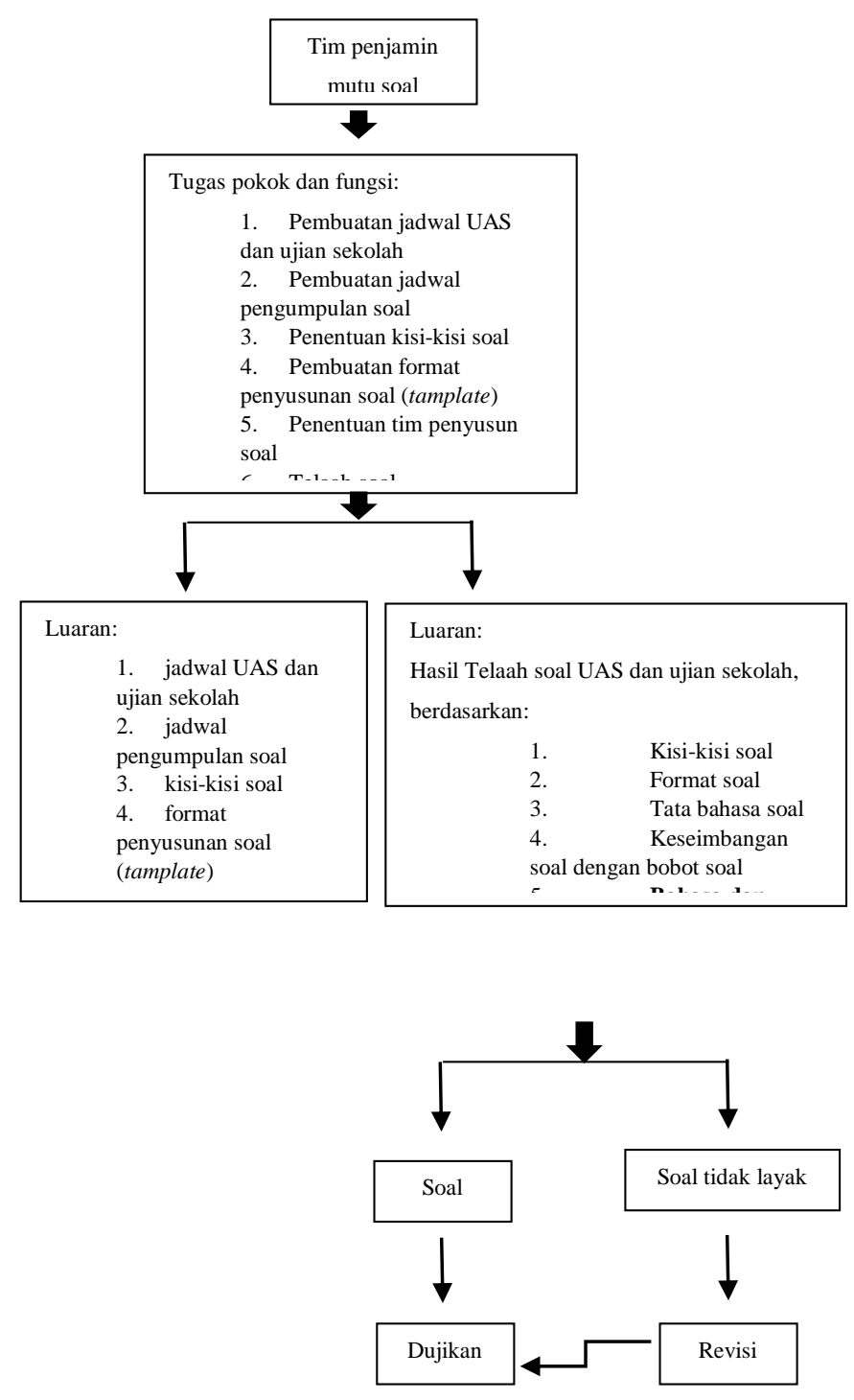

Soal yang telah dihasilkan melalui tim penjamin mutu soal diketahui mampu mengakomodasi semua materi pada mata pelajaran yang diajarkan di kelas. Dalam pembelajaran tematik, tim penjamin mutu soal melalui penentuan kisi-kisi memberikan cek list daftar isian untuk memastikan bahwa semua materi telah terakomodasi dalam soal PAS untuk kelas 1-5. Hasil analisis kesesuaian kisi-kisi dengan soal menunjukkan kesesuaian antara materi yang dipelajari dengan soal yang ada pada saat PAS. Oleh karena antara materi yang dipelajari dengan soal-soal yang diujikan telah sesuai, maka secara langsung ataupun tidak langsung hal inilah yang mampu meningkatkan hasil belajar siswa. Sedangkan pada saat ujian sekolah untuk kelas 6, telah menggunakan soal yang layak diujikan. Namun demikian, muncul pertanyaan besar yang perlu untuk didiskusikan adalah penerapan ujian sekolah per mata pelajaran. Dalam pelaksanaan pembelajaran di kelas, proses dilakukan dengan pembelajaran tematik. Namun, ujian sekolah dilakukan setiap mata pelajaran. Para guru kesulitan untuk mengatur waktu antara menyelesaikan materi pembelajaran tematik dengan fokus pada persiapan ujian. Tidak sedikit para guru di kelas 6 yang pada akhirnya berorientasi pada ujian, bukan pada proses. Pada akhirnya, hal inilah yang menjadi cikal bakal membuka kesempatan munculnya generasi instan di masa kini. Oleh karenanya, SD Muhammadiyah 9 memberikan kebijakan kepada para guru di kelas 6 untuk mengatur waktu dengan baik antara melaksanakan proses dengan persiapan ujian. Kebijakan tersebut diejawantahkan pada jadwal pembelajaran di kelas.

\section{KESIMPULAN}

Peningkatan hasil belajar dipengaruhi oleh faktor dari internal maupun dari eksternal. Faktor internal dipengaruhi oleh diri masing-masing siswa. Sedangkan faktor eksternal dipengaruhi oleh lingkungan sekitar. Termasuk diantaranya adalah proses penilaian yang dilakukan. Dalam penilaian, soal yang digunakan untuk mengevaluasi hasil belajar juga harus sesuai dengan proses pembelajaran yang 
dilakukan. Proses penyesuaian ini merupakan salah satu tugas pokok penjaminan mutu soal. Oleh karenya, penjaminan mutu soal secara langsung maupun tidak langsung mampu meningkatka hasil belajar siswa

\section{E. Masalah Terbuka}

Berdasarkan uraian di atas, muncul masalah terbuka sebagai berikut.

1. Pelaksanaan ujian sekolah perlu ditinjau ulang, jika pembelajaran yang dilakukan adalah pembelajaran tematik dan ujian sekolah dilakukan per mata pelajaran.

2. Manajemen waktu bagi guru, antara penyelesaian materi pembelajaran dengan pelaksanaan ujian sekolah.

3. Peningkatan kualitas soal, dari Low order thingking skill (LOTS) menjadi high order thinking skill (HOTS)

\section{DAFTAR PUSTAKA}

104, P. M. N. (2014). Lampiran Tentang Penilaian Hasil Belajar oleh Pendidik pada Pendidikan Dasar dan Pendidikan Menengah. Pedoman Evaluasi Kurikulum, (13), 13,23.

Azis, A. (2014). Kompetensi Guru Dalam Penggunaan Media Dengan Mutu Pendidikan. Jurnal Pelopor Pendidikan, 5(1), 49-58. Retrieved from http://www.stkippgrismp.ac.id/jurn al-pelopor-pendidikan-3/

Bundsgaard, J., \& Hansen, T. (2011). Evaluation of Learning Materials: A Holistic Framework. Journal of Learning Design, 4(4), 31-45. https://doi.org/http://dx.doi.org/10. 5204/jld.v4i4.87

Deng, L., \& Yu, D. (2013a). Deep

Learning: Methods and Aopplications. Foundations and Trends in Signal Processing, 7(3-
4), 197--387.

https://doi.org/10.1136/bmj.319.72 $09.0 \mathrm{a}$

Deng, L., \& Yu, D. (2013b). Deep

Learning: Methods and

Applications. Foundations and

Trends ${ }^{\circledR}$ in Signal Processing, 7(3-4), 197--387. https://doi.org/10.1561/200000003 9

Felder, R., \& Brent, R. (2005).

Understanding student differences. Journal of Engineering Education, 94(1), 57-72.

https://doi.org/10.1002/j.21689830.2005.tb00829.x

Hadi, S. (2014). Ujian nasional dalam tinjauan kritis filsafat pendidikan pragmatisme. Ilmiah Pendidikan Guru Madrasah Ibtidaiyah, IV Nomor 1, 283-294. Retrieved from http://www.academia.edu/downloa d/36815687/UJIAN_NASIONAL_ DALAM_TINJAUAN_KRITIS_F ILSAFAT_PENDIDIKAN_PRAG MATISME__SUMASNO_HADI.pdf

Hadiana, D. (2015). Penilaian Hasil Belajar Untuk Siswa Sekolah Dasar Assessment of Learning Outcomes for Elementary School Students. Jurnal Pendidikan Dan Kebudayaan, 21(1), 15-26.

Lambertus. (2009). Pentingnya Melatih

Keterampilan Berpikir Kritis

Dalam Pembelajaran Matematika

Di SD. Forum Pendidikan, 28(2), 136-142.

Moeljadi Pranata. (2004). Portofolio:

Model Penilaian Desain

Berbasiskan Konstruktivistik. Nirmana, 6(1992), 63-81.

Pratistya, N. A., \& Abdullah, T. (2012). Pengaruh Kemandirian Belajar dan Lingkungan Belajar Siswa Terhadap Prestasi Belajar. Jurnal Pendidikan, X(1), 48-65. 
20 Jurnal Pemikiran dan Pengembangan SD, Volume 6, Nomor 1, April 2018 hlm 12-20

Yubali, A. (2013). Penilaian Autentik

Pada Kurikulum 2013. Seminar
Nasional Implementasi Kurikulum

2013, 742-749. 